\title{
O działalności organów samorządu terytorialnego miasta Świdnicy w świetle ordynacji miejskich z lat 1815-1871
}

Z szeregu reform administracyjnych przeprowadzonych w państwie pruskim w początkach XIX wieku kluczowe znaczenie dla funkcjonowania organizmów municypalnych odegrała ordynacja miejska z 1808 r. (Städte-Ordnung), kwalifikowana jako mała konstytucja samorządu terytorialnego. Była jedną z pierwszych nowożytnych regulacji prawnych, zrywających z feudalną koncepcją miasta. Głównym założeniem ministra Friedricha Karla Steina (1757-1831), inicjatora i współtwórcy reformy administracji samorządowej, było zorganizowanie gminy miejskiej w duchu samodzielności społecznej. I nie chodziło jedynie o uczynienie z miast publicznoprawnych korporacji, ile włączenie czynnika społeczności lokalnej w funkcjonowanie administracji publicznej ${ }^{1}$. Drugim, jeśli nie kluczowym katalizatorem reorganizacji struktur samorządowych i gruntownej reformy stanowej w pruskiej monarchii była konieczność pozyskania mas społecznych, zdolnych walczyć z francuskim okupantem. Nie kto inny, jak mieszczaństwo i chłopi mieli wziąć na swoje barki ciężar kosztów wojennych, a zachęcić ich do tego miały licznie nadawane wolności i przywileje².

Myślą przewodnią ordynacji miejskiej, uchwalonej 19 listopada 1808 r., zdaje się być potrzeba aktywizacji mieszkańców miast w dziedzinie administracji samorządowej, tym samym zaś do wpływania na kształt lokalnej polityki. Do władzy dopuszczono mieszczan, choć ta pozorna namiastka demokracji opierała się nadal na podziale społecznym na wyższe i niższe warstwy. Wartym podkreślenia novum było odejście od politycznego uprzywilejowania stanów na rzecz kryterium majętności mieszczan. Od tej pory naturalną granicę stanowił jedynie cenzus majątkowy, będący solidną barierą na drodze ku pełni praw obywatelskich (mieszczańskich). Majętny rzemieślnik miejski został zrównany w prawach z miejską arystokracją. Potencjalnie mógł zasiadać

\footnotetext{
${ }^{1}$ J. Panejko, Geneza i podstawy samorzadu europejskiego, Paryż 1926, s. 31.

${ }^{2}$ T. Kulak, Historia Wrocławia. Od twierdzy fryderycjańskiej do twierdzy hitlerowskiej, t. 2, Wrocław 2001, s. 129-130.
} 
w radzie miejskiej, w ten sposób otrzymując możliwość współdecydowania o lokalnej polityce: „Kto tylko parał się rzemiosłem miejskim bądź posiadał nieruchomość $\mathrm{w}$ mieście, zmuszony był nabyć prawa miejskie, a co się z tym wiązało - również spełniać obowiązki obywatelskie"3. Warto nadmienić, iż obywatelstwo nadawane było przez magistrat, po uprzednim wysłuchaniu reprezentantów. W mniejszych miastach wymagano, aby roczny przychód na osobę przekraczał 150 talarów, w większych - 200 talarów.

Ogół obywateli stanowił gminę miejską. Ta zaś dzielona była na „mieszczan” (Bürger) i „podopiecznych” (Schutzverwandte), obejmując ostatnim pojęciem warstwę społeczeństwa, która nie posiadała praw miejskich, np. robotników dziennych, czeladników. Żyli on w miejskiej społeczności i podlegali jedynie jej ochronie. Nie przysługiwały im jakiekolwiek prawa polityczne; zarazem zwolnieni byli z ponoszenia ciężarów komunalnych. Status obywatela nabywali z mocy prawa mieszczanie ,zasiedziali”, miejscowi, po upływie roku od dnia osiedlenia się w mieście. Poza kryterium domicylu, członkowie wspólnoty mieszczan winni też byli posiadać nieruchomość na obszarze miasta oraz wykonywać „mieszczański” zawód, do grupy których zaliczano profesje handlarza, rzemieślnika, przemysłowca lub też specjalność z grupy zawodów wolnych i uczonych oraz ponosili ciężar uiszczania miejskich podatków z tytułu wykonywanego zawodu oraz posiadanej nieruchomości. Utrata obywatelstwa następowała wskutek popełnienia określonego przestępstwa. Wiązało się to również z utratą prawa własności nieruchomości miejskich i zakazem wykonywania rzemiosła w mieście.

Na mocy ordynacji dotychczasowy podział na miasta królewskie i miasta prywatne został definitywnie zniesiony, a co się z tym wiązało - każdy pruski ośrodek miejski został podporządkowany władzy państwowej. Od tej pory wszystkie miasta cieszyły się przywilejem wolności. Ordynacja wyróżniała jednak podział pod względem zaludnienia na miasta małe (poniżej 3500 mieszkańców), średnie (od 3500 do 10 000) oraz większe (ponad 10000 mieszkańców). W ich granice włączono przedmieścia. W tym też okresie (1816 r.) Świdnica z liczbą 9849 plasowała się jako ośrodek miejski średniej wielkości.

Najbardziej istotnym zagadnieniem regulowanym treścią ordynacji był ustrój samorządu miejskiego. Reprezentację mieszczan stanowiła rada miejska (Stadtverordnetenversammlung), wybierana przez ogół uprawnionych do głosowania obywateli, w głosowaniu bezpośrednim i tajnym. W zależności od kategorii miast, w skład organu wchodziło od 26 do 34 (w miastach małych), w średnich - od 36 do 60, w większych zaś od 60 do 102 radnych. Skład rady odnawiany był corocznie w jednej trzeciej liczby jej członków. Organ ten spełniał głównie funkcje uchwałodawcze i kontrolne względem magistratu, będącego ciałem wykonawczym miejskiego samorządu. Rada wybierała

${ }^{3}$ F.J. Schmidt, Geschichte von Schweidnitz, t. 2, Schweidnitz 1848, s. 343. 
jego członków, zaś ostateczna decyzja dotycząca składu magistratu zależała od zatwierdzenia władz prowincjonalnych. Przedmiotem działalności uchwałodawczej rady uczyniono sprawy dotyczące danin komunalnych (wprowadzanie nowych podatków, ustalanie wysokości opłat, sposób ich repartycji), stanowienie generalnych wytycznych w zarządzaniu interesami miasta, jak również w wielu innych drobniejszych sprawach społeczności lokalnej ${ }^{4}$.

Władza administracyjna spoczywała w rękach kolegialnego magistratu, wyłanianego $\mathrm{w}$ drodze wyborów rady miejskiej. Na jego czele stał burmistrz (w większych miastach nosił tytuł nadburmistrza) powoływany na dwunastoletnią kadencję $e^{5}$. Miał szeroki zakres czynności i znaczne kompetencje. Był zwierzchnikiem wszystkich urzędników. $Z$ tytułu przewodniczenia kolegium magistrackiemu, do jego obowiązków należało kierowanie pracą magistratu, wydawanie zarządzeń i instrukcji w tym zakresie, dbałość o sprawne i transparentne funkcjonowanie całej administracji samorządowej, także o porządek i przyzwoite zachowanie się członków magistratu podczas posiedzeń ${ }^{6}$. Wśród szeregu prerogatyw do kluczowych należały nadzór i osobista kontrola nad finansami miejskimi zarządzanymi za pośrednictwem wyspecjalizowanych kas, nadzór i kontrola nad zarządem legatów i fundacji, prowadzenie spraw dyscyplinarnych z prawem nakładania kar do 5 talarów oraz 4 dni aresztu. Na jego osobie spoczywał też ciężar dotrzymywania zobowiązań wobec królewskiego fiskusa i urzędów państwowych. W taki sposób burmistrz stał na straży praworządności i dbałości o interesy państwa. Poza funkcją reprezentacyjną, w swoich rękach skupiał uprawnienia organu policyjnego. W większych miastach, np. Wrocławiu, Legnicy, Brzegu, Nysie czy w Swidnicy, funkcje te rozdzielano i działania prewencyjno-represyjne przejmowały tzw. prezydia policji, w których strukturach zatrudniano kilkunastu bądź kilkudziesięciu funkcjonariuszy. W Świdnicy funkcję tę sprawował dyrektor policji (PolizeiDirector), do którego kompetencji należało, poza nakładaniem kar za występki (Contraventionen), wydawanie zarządzeń (Verordnungen) o charakterze porządkowym. Wydawał również pozwolenia na wyszynk, organizowanie zabaw publicznych i potańcówek ${ }^{7}$. W gestii magistratu zaś leżało, poza sprawowaniem funkcji administracyjnej, obsadzanie niższych stanowisk, nadawanie obywatelstwa, ograniczona kontrola publicznych kas, czy udzielanie tzw. kart przemysłowych $^{8}$ (Gewerbeschein), które uprawniały do wykonywania kon-

${ }^{4}$ K. Ciesielska, Ustrój i organizacja władz i kancelarii miasta Torunia w latach 1793-1919, Warszawa 1972, s. 63-65.

${ }^{5}$ K. Genschmar, Die Preußische Städteordnung des Freiherrn vom Stein vom 19.11.1808, Norderstedt 2003, s. 8.

${ }^{6}$ K. Ciesielska, op. cit., s. 51.

${ }^{7}$ L. v. Rönne, H. Simon, Das Polizeiwesen des Preußischen Staates, t. 2, Breslau 1841, s. 486.

${ }^{8}$ Inaczej też świadectw przemysłowych. Kompetencja ta przypadła magistratowi w 1820 r., wraz z wejściem w życie nowej ustawy o podatku przemysłowym. Do tej pory organem właściwym była dyrekcja policji. 
cesjonowanych zawodów. Działalność magistratu pozostawała pod kontrolą miejskiego parlamentu. Pozostałe aspekty miejskiego życia, w tym m.in. sprawy kościelne, szkolne, opieki społecznej, budowlane, gospodarki leśnej, należały do kompetencji specjalnie tworzonych deputacji bądź komisji, w skład których, poza delegowanymi członkami magistratu i rady miejskiej, wchodzili ,apolityczni” mieszczanie, werbowani z zamożniejszych warstw społecznych i cieszący się przywilejami obywatelskimi ${ }^{9}$.

Deputacje miejskie i komisje były organami kolegialnymi funkcjonującymi przy magistracie. Do ich zadań należało w pierwszej kolejności administrowanie poszczególnymi gałęziami miejskiej gospodarki. Poza stałymi formami ich działalności, powoływano także doraźne deputacje, specjalnie dla jednorazowego załatwienia określonych zadań. Funkcje przewodniczącego składu pełnił zawsze członek magistratu, gdy jednak było ich dwóch bądź więcej - najstarszy stażem ${ }^{10}$. Szczególnym przywilejem cieszył się burmistrz miasta, który posiadał prawo wzięcia udziału w posiedzeniach wszystkich deputacji i niezależnie od tego, czy był ich członkiem, czy nie. Jemu też przysługiwało prawo do głosowania przeprowadzanego podczas narad i wnoszenia spraw pod obrady. Przez lata tworzono szereg nowych komisji i deputacji, tak że w 1869 r. przy świdnickim magistracie funkcjonowało ich 31:

1. Deputacja ds. opłat (Abgaben-Deputation) - składała się z 4 członków magistratu i 22 radnych, względnie mieszczan wraz z członkami magistratu;

2. Deputacja ds. ubogich (Armen-Deputation) - skład: nadburmistrz z 3 członkami magistratu i 12 radnymi;

3. Deputacja ds. umarzania miejskich obligacji (Ausloosung-Deputation der Schweidnitzer Stadt-Obligationen) - 2 członków magistratu oraz 2 radnych bądź mieszczan;

4. Deputacja budowlana (Bau-Deputation) - 4 członków magistratu i 10 radnych bądź mieszczan;

5. Deputacja ds. pomiarów (Eichungs-Deputation) - miejski radca budowlany i mistrz pomiarowy (Eichungsmeister);

6. Deputacja ds. towarzystw ogniowych (Feuer-Societäts-Deputation) - miejski radca budowlany i 4 członków;

7. Deputacja leśna (Forst-Deputation) - 12 członków;

8. Deputacja finansowa (Finanz-Deputation);

9. Deputacja ds. gratulacji (Gratulations-Deputation);

10. Deputacja ds. szpitalnictwa (Hospital-Deputation);

${ }^{9}$ Neue Sammlung aller in der souverainen Herzogtum Schlesien und der demselben incorporirten Graffschaft Glatz, t. 10, Breslau 1823, s. 190 i n.

${ }^{10}$ L. von Rönne, Die preussischen Städte-Ordnungen vom 19. November 1808 und vom 17. März 1831 mit ihren Ergänzungen und Erläuterungen durch Gesetzgebung und Wissenschaft, Breslau 1840, s. 230. 
11. Kuratorium miejskiego lombardu (Leihamts-Curatorium) - 4 członków magistratu oraz 4 radnych bądź mieszczan;

12. Deputacja ds. masztalni (Marstall-Deputation);

13. Deputacja ds. kurateli miejskiego budżetu (Kämmerei-KuratelDeputation);

14. Komisja sanitarna (Sanitäts-Kommission);

15. Deputacja ds. szkolnictwa (Schul-Deputation);

16. Komisja ds. służby wojskowej i kwaterunku (Servis- und Einquartierungs-Kommission);

17. Deputacja ds. bezpieczeństwa (Sicherungs-Deputation);

18. Kuratorium miejskiej kasy oszczędnościowej (Sparkassen-Kuratorium);

19. Deputacja ds. więzienia (Stockhaus-Deputation);

20. Rada miejska (Stadtverordneten-Versammlung) - skład w 1870 r.: przewodniczący - aptekarz Sommerbrodt, zastępca przewodniczącego - kupiec Rosenthal, protokolant - wytwórca sukna Sölter, zastępca protokolanta - radca prawny Koch, radni - Kaatz sen., Döll, Heiler, Pieh, Nitschke, Geisler sen., Janeck sen., Bartels, Rätze, Groeger, Schmidt, Urban, Koch sen., Schubert sen., dr med. Meyer, Pohl, Birner, Steinbrück, Stockmann, prof. dr Schmidt, König, Tschöpe, Biestert, Müller, Beyer, Mühsam, Peter, Meyer, H. Geisler, Neumann, Schindler, Opitz;

21. Rada ds. sportu (Turnrath);

22. Deputacja ds. miejskiej cegielni (Ziegelei-Deputation);

23. Deputacja ds. przemysłu (Gewerbe-Deputation);

24. Deputacja ds. zakładu gazowniczego (Gasanstalts-Deputation);

25. Naczelna rada nad zarządem okręgów miejskich - na czele z nadburmistrzem;

26. Komisja ds. kwalifikacji gruntów na sprzedaż (Kommission zur Prüfung verkäuflich werdender Grundstücke);

27. Komisja konsultacyjna ds. miejskiego planu budowlanego (Kommission zur Berathung über den Stadtbebauungsplan);

28. Deputacja ds. składu drewna (Holzhofs-Deputation); sion);

29. Komisja ds. przejmowania fortyfikacji (Festungs-Übernahme-Kommis-

30. Komisja ds. szacunku i wymiaru podatku klasowego (KlassensteuerEinschätzungs-Kommission);

31. Deputacja ds. promenady miejskiej (Promenaden-Deputation $)^{11}$.

Drugą osobą po burmistrzu w urzędniczej hierarchii był komornik, często zwany też kamelarzem (Kämmerer). Urzędnik ten, piastujący płatny urząd,

${ }^{11}$ Bericht über die Verwaltung und die Stand der Gemeinde-Angelegenheiten der Stadt Schweidnitz für das Jahr 1869, Schweidnitz 1870, s. 98-102. 
wchodził również w skład kolegium magistrackiego. Jemu też powierzano kluczowe z gospodarczego punktu widzenia kompetencje. Kamelarzowi podlegał całokształt gospodarki finansowej gminy; odpowiadał on za poprawne prowadzenie miejskich rachunków, sprawował zarząd nad majątkiem gminnym i załatwiał wszelkie sprawy rachunkowo-kasowe ${ }^{12}$.

Doradztwo prawne w działaniach urzędników samorządowych oraz zapewnienie zgodności przedsiębranych czynności należało do zadań miejskiego syndyka. Jemu przypisywana była odpowiedzialność za ich zgodność z prawem państwowym i lokalnymi przepisami. Syndyk występował również jako biegły, przygotowywał procesy prowadzone przez gminę miejską, dbał o formalną poprawność wszelkich umów i układów, w których stroną był magistrat, jak również o jasność i precyzyjność ich postanowień. Na jego barkach spoczywała odpowiedzialność za wszelkie spory prawne i szkody, wynikające z zaniedbania i nieprzestrzegania form prawnych. Wreszcie, prowadził dochodzenia w postępowaniu dyscyplinarnym względem urzędników niższego szczebla, rozstrzygał także spory w cechach, jeśli tylko asesorzy nie byli w stanie ich rozstrzygnąc $c^{13}$.

W miastach liczących ponad 800 mieszkańców, obszar dzielono na obwody/okręgi (Bezirken), zarządzane przez podległych magistratowi urzędników, tzw. Bezirkvorsteher, którzy wywodzili się z ,zasiedziałych właścicieli domów, cieszących się szacunkiem sąsiadów". Wybierani byli przez radę miejską na sześcioletnią kadencję ( $§ 163$ ). Ich rola sprowadzała się głównie do pośredniczenia między administracją samorządową a mieszkańcami okręgów, sprawowania kontroli i nadzoru nad przestrzeganiem prawa miejscowego, procedurą głosowania w wyborach do rady miejskiej, inspekcji miejscowych instalacji wodociągowych, warunków sanitarnych, stanu czystości ulic, placów czy studni publicznych, leżących w podlegającym im okręgu. W Świdnicy wyróżniano 10 obwodów administracyjnych: Markt-, Burggasse-, Petersgasse-, Hohgasse-, Langgasse-, Kroischgasse-, Kupferschmiedegasse-, Breslauer- und Niedevorstadtr-, Neustadt-, Striegauer- und Kirchvorstadt- ${ }^{14}$ i, od 1853 r. jedenasty - Kletschkauervorstadt-Bezirk, będących jednocześnie okręgami wyborczymi ${ }^{15}$.

${ }^{12}$ K. Ciesielska, op. cit., s. 51-52.

${ }^{13}$ Ibidem.

${ }^{14} \mathrm{Na}$ podstawie zarządzenia o wyborach sędziów rozjemców w poszczególnych obwodach miejskich, granice administracyjne przedmieść kształtowały się w następujący sposób: BreslauerVorstadt - domy nr 413--463, Nieder-Vorstadt - nr 464-505, Neustadt - nr 506-581, Striegauer-Vorstadt - 582-636: Bekanntmachung nr 70. Wegen der Schiedsmänner, [w:] Obrigkeitliche Bekanntmachungen [Schweidnitz] 1834, nr XX.

${ }^{15}$ Zgodnie z $§ 12$ ordynacji, nazwa okręgu miała pochodzić od nazwy głównego ciągu komunikacyjnego bądź placu, położonego w granicach tego okręgu. Przy czym w miastach średnich, do których zaliczała się Świdnica, liczba mieszkańców okręgu nie mogła być większa niż 1000 i mniejsza niż 400. 
Początkiem 1809 r. przystąpiono do wdrażania ordynacji w życie. Pierwsze wybory do miejskiej rady miały miejsce w niedzielę 12 lutego. Wybrano czterdziestoosobową reprezentację do miejskiego parlamentu (Stadtverordneten-Versammlung), przy wsparciu 20 zastępców (Stellvertretern). Dla porównania, w 1809 r. we Wrocławiu wybierano 102, w Głogowie i Zielonej Górze po 45, w Kowarach i Ząbkowicach - 36, Lwówku Śląskim - 30, w Mirsku, Wałbrzychu i Ścinawie po 24, a w Lewinie Kłodzkim i Miliczu - 12 radnych ${ }^{16}$. Na urząd przewodniczącego rady prawie jednogłośnie powołano superintendenta pastora Georga Augusta Kunowskiego, cieszącego się znacznym poparciem członków, w większości deklarujących konfesję ewangelicką. Wybór osoby duchownego zdaje się symptomatyczny w owym czasie, po upadku reżimu administracyjnego zwierzchnictwa państwa nad działalnością samorządów. Wynik głosowania spotkał się z opozycją władz rejencji dzierżoniowskiej, które odmówiły zatwierdzenia wyboru. W uzasadnienie decyzji wskazano, iż taki stan rzeczy stoi w sprzeczności z postanowieniami ordynacji miejskiej, w szczególności z zawartą w $§ 116^{17}$ zasadą incompabilitas, na podstawie której urzędnik państwowy nie mógł jednocześnie pełnić funkcji przewodniczącego rady miejskiej. Jak wielkie znaczenie miał wybór Kunowskiego dla miejscowych włodarzy, świadczy fakt, iż członkowie magistratu, niezwłocznie po otrzymaniu odmownej decyzji, zwrócili się z petycją do króla o uczynienie zadość woli społeczności lokalnej, w treści podnosząc:

Zarówno superintendent Kunowski, jak i diakon Höppe ${ }^{18}$ żyją wśród nas szereg długich lat. Przez ten czas mieli oni sposobność, aby zarówno nam, jak i mieszkańcom miasta dowieść hart swojego ducha i niezłomność charakteru. [...] W rezultacie cieszą się oni zasłużonym poważaniem i powszechnym uwielbieniem. Obdarzeni talentem doskonałego mówcy zdobyli nasze uznanie, a wywierany przez nich wpływ na usposobienie mieszczan, przede wszystkim zaś umacnianie ducha patriotyzmu przy każdej nadarzającej się okazji, zasługują w najwyższym

${ }^{16} \mathrm{~W}$ opracowaniu pod red. Michalkiewicza błędnie podano liczbę 200 radnych Wrocławia: Historia Ślaska, t. 2, cz. 2, 1807-1850, pod red. St. Michalkiewicza, Wrocław 1970, s. 293.

${ }^{17}, \S 116$. Pr z e w o d n i c zą c y i protok olant. Zgromadzenie radnych zatwierdza przewodniczącego i protokolanta oraz po jednym zastępcy dla każdego z nich. Są oni wybierani spośród członków zgromadzenia radnych na okres jednego roku. Jedynie sługa państwowy i praktykujący prawnik nie są zdolni do pełnienia tych funkcji. W przypadku złożenia mandatu przez przewodniczącego bądź protokolanta w czasie ich kadencji, funkcję tą pełni ich zastępca do czasu przeprowadzenia nowych wyborów": L. von Rönne, Die preussischen Städte-Ordnungen, s. 142143. W chwili wyboru Kunowskiego obowiązywał zaledwie zakaz łączenia funkcji urzędnika państwowego z samorządowym, zaś ustawa milczała na temat stanu duchowieństwa. Tekst pierwotny przepisu znowelizowano dopiero w 1832 r. poprzez dodanie zdania: „Również duchowni nie są uprawnieni do pełnienia funkcji przewodniczącego i protokolanta rady miejskiej, ani ich zastępców": J.E.Th. Janke, Abhandlungen über einige der wichtigsten Theile der preußischen Städte-Ordnung, Städte-Verwaltung und Kommunal-Verfassung, t. 1, Potsdam 1833, s. 343.

${ }^{18}$ Duchowny ewangelicki przy świdnickim Kościele Pokoju, który miał zostać powołany na zastępcę przewodniczącego rady miejskiej. 
stopniu na pochwałę. Bezgraniczne oddanie dworowi Jego Królewskiej Mości, miłość do ojczyzny i wierność cnotom, które Wasza Królewska Miłość z roztropnością i pełnią łaski wciąż w nas rozpalasz, a które to wielokroć były obecne w Twoich mowach, dawały nam ukojenie w ciężkich czasach. Bowiem zarówno słowa, jak i przykład Twojego postępowania wskazują nam, jak winniśmy wypełniać nasze powinności wobec Boga i czynić zadość naszym obowiązkom wobec ojczyzny.

Tak zredagowany postulat nie spotkał się jednak z akceptacją monarchy. Mimo odmowy pełnienia przez Kunowskiego funkcji przewodniczącego, zezwolono mu w drodze wyjątku na przewodniczenie radzie miejskiej na czas wprowadzania $\mathrm{w}$ życie postanowień ordynacji miejskiej ${ }^{19}$. Na jego miejsce ostatecznie wstąpił piekarz Thamm, który przez długie lata cieszył się estymą przewodniczącego rady.

12 kwietnia 1809 r., podczas głosowania w miejskim parlamencie, wyłoniono pierwszy skład magistratu. Cały przebieg zgromadzenia ujęto w odświętne ramy, mając w świadomości doniosłość chwili w historii miasta. O wczesnej godzinie porannej radni zgromadzili się w domu przewodniczącego Thamma, po czym udali się w odświętnym pochodzie do izby protokolanta Carla Benjamina Höhlmanna, gdzie przystąpiono do głosowania. Przedtem jednak przewodniczący rady, protokolant i radny Kunowski nie szczędzili wzniosłych słów wychwalających ustrój, konstytucję i znaczenie tego dnia w dziejach Świdnicy. W efekcie głosowania wybrano 12 nowych członków magistratu (Raths) ${ }^{20}$, spośród których na urząd burmistrza (Bürgermeister) powołano Johanna Benjamina Kuschego ${ }^{21}$, syndyka (Syndikus) ${ }^{22}$ Heinricha i komornika (Kämmerer) Lieniga, uchwalając uposażenia odpowiednio w wysokości 1200, 1000 i 900 talarów. Na tę okoliczność Kusche wygłosił krótką mowę, wyrażając swoją wdzięczność za dowód zaufania i wiary, jakimi darzono jego osobę. W liście do radnych pisał:

$\mathrm{Z}$ drżeniem serca przyjmuję wybór mojej osoby; niebiosa niech obdarzą mnie siłą, aby mógł podołać zadaniom, stawianym przede mną i których trud wypeł-

${ }_{19}$ W.G. v. Kunowski, Zum 100. Todestage von George August Kunowski. Erinnerungen an das Leben und Wirken eines bekannten Schweidnitzer Superintendenten, „Tägliche Rundschau für Mittelschlesien" 1938, nr 16.

${ }^{20}$ Skład pierwszego magistratu powołanego na mocy ordynacji miejskiej z 1808 r.: Kusche, Heinrich, Lienig, Langer, Birkenstock, John, Leo, Steibrick, Thomas, Bettauer, May, Steinhauer: „Schweidnitzer Erzähler” 1810, nr 16.

${ }^{21}$ Przed reformą administracyjną Kusche piastował urząd wicedyrektora (Vicedirektor) zarządu miasta. Ostatni skład magistratu przedstawiał się w następujący sposób: dyrektor Carl Schnieber, wicedyrektorzy Kusche i von Steinwehr, syndyk Christian Friedrich Berger (APWr, AmŚw, sygn. 142, k. 422), komornik Lienig, von Gerskow, Neumann, Heinrici, Langer, Leo (†1833), Kallinich, Scholz oraz Böhm.

${ }^{22}$ Odpowiednik pisarza miejskiego. 
niania jestem przygotowany ponosić. Obdarzcie mnie swoim zaufaniem, a podejmowane przeze mnie kroki i działania oceniajcie podług waszych kryteriów. Taka jest moja wola; zatwierdzenie przez Was mojej osoby jest warunkiem, abym dalej mógł spełniać swoją urzędniczą powinność.

Wprowadzenie na urząd miało miejsce 14 czerwca, poprzedzone nabożeństwem w Kościele Pokoju i uroczystym zaprzysiężeniem nowo wybranej reprezentacji mieszczan Świdnicy. Znamienne były też słowa Kuschego:

Co dziś przysięgaliśmy przed obliczem Boga, niech będzie nam przypominane przez naszych czcigodnych mieszczan. Wyrażamy niezłomną wolę trwania w wierności królowi, zawierzamy się ojczyźnie i poprzysięgamy posłuszeństwo naszym zwierzchnikom oraz że z gorliwością i niesłabnącym zapałem czynić będziemy wszystko, co najlepsze dla naszego miasta. Nie będziemy szczędzić trudu i wysiłku, działając zarówno dla dobra ogółu, jak i każdego z osobna. Przysięgamy też sumiennie zarządzać wspólnym majątkiem. Nikt nie zostanie wydalony z miasta z tej przyczyny, że na wyrządzoną mu przez nas niesprawiedliwość odpowie skargą; potrzebujący wsparcia nie obejdzie się bez pocieszenia, a każdemu w biedzie, stosownie do naszych sił i możliwości, postaramy się spieszyć z pomocą. Powoli zabliźniać się będą rany, jakie zadał nam okrutny los; powoli też odradzać się będzie nasz wspólny dobrobyt. Chcemy obdarzać jednakową miłością zarówno ubogich, jak i zamożnych; szerzyć dobro, zaś złu zapobiegać i jedynie dzięki pilnemu wypełnianiu nałożonych na nas obowiązków oraz umiłowaniu porządku zasłużyć na chwałę i Wasze uznanie. A najwyższą zapłatą za nasz trud i poświęcenie będzie uznanie naszych przełożonych, zadowolenie zaś wciąż darzących nas zaufaniem obywateli - naszą dumą ${ }^{23}$.

Zarówno radnych jak i członków magistratu czy deputacji obowiązywał strój urzędowy i stosowne emblematy. W służbie miejskiej społeczności, podczas wspólnych posiedzeń, reprezentanci winni byli być przyodziani w czarny strój. Urzędnicy magistratu mieli obowiązek nosić srebrny łańcuch z medalem odlanym z tego samego kruszcu, radni miejscy zaś - srebrny medal na wstędze obszytej srebrną lamówką.

Dwór pruski kierowany potrzebą pokrycia ogromnych sum zadłużenia wojennego wydał 30 października 1810 r. edykt sekularyzacyjny, mocą którego przejął na rzecz królewskiego skarbu zarówno nieruchomości i majątek ruchomy, do tej pory skupiony w rękach zgromadzeń zakonnych. Postanowieniom tym oparły się jedynie te konwenty, które w swojej powszedniej działalności parały się edukacją młodzieży i szpitalnictwem. Świdnica jeszcze w początkach XIX stulecia była siedzibą dominikanów, których zabudowania zakonne (zajęte następnie przez królewski inkwizytoriat) wraz z kościo-

${ }^{23}$ J. Held, Erinnerung an Johann Benjamin Kusche. Zur Feier der Einweihung des neuen Gymnasialgebäudes im Schweidnitz am 15. October 1854, Schweidnitz 1854, s. 10. 
łem św. Krzyża wznosiły się w kwartale ograniczonym ulicami Croischstr., Rosenstr., Bögenstr. i murem miejskim, biegnącym wzdłuż dawnej Fiedlergasse. Przy Köppenstr. swoją siedzibę znaleźli franciszkanie. Zabudowania klasztorne w 1821 r. przeznaczono na siedzibę królewskiego Sądu Miejskiego (Kgl. Stadtgericht), a sąsiadujący kościół pw. Najświętszej Marii Panny przez jakiś czas spełniał rolę magazynu solnego. Budynki komandorii krzyżowców z czerwoną gwiazdą wraz z kościołem św. Michała przed Bramą Dolną, przeszły w ręce prywatne. We wnętrzach urządzono izby mieszkalne oraz wygospodarowano powierzchnie handlowe. Jedyny w mieście żeński zakon urszulanek (mieścił się przy Kupferschmiedestr.), prowadzących szkołę przyklasztorną, oparł się kasacie.

Okres rządów Kuschego spotykał się z pozytywną oceną zarówno ówczesnych obserwatorów działań podejmowanych przez świdnicki magistrat, jak i późniejszych historiografów oceniających jego polityczną drogę z perspektywy czasu. Do jego koronnych osiągnięć zaliczano utworzenie gminnego przytułku dla ubogich z domem pracy przymusowej, prowadzącego także działalność ambulatoryjną (Armen-, Kranken- und Arbeitshaus). Placówkę ulokowano w należących do rodziny von Nostiz pomieszczeniach byłego klasztoru Kapucynów przy Burgplan. Działania wojenne znacznie nadszarpnęły konstrukcję poprzedniego budynku zajmowanego pod działalność przytułku. Miejski skarbiec świecił pustkami, toteż o pozyskanie nowego obiektu zwrócono się do króla sprawującego zarząd nad fiskalnym majątkiem nieruchomym. Pruski monarcha pozytywnie zaopiniował skierowany do niego memoriał, stawiając jedocześnie jeden warunek. Prawowici właściciele zabudowań klasztornych zrzekną się wszelkich roszczeń do tej nieruchomości. Kusche w kilku zgrabnie zredagowanych zdaniach zwrócił się do hrabiego von Nostitz und Rieneck z prośbą, aby mimo braku zobowiązań wobec miasta, dla dobra miejscowych potrzebujących ten odstąpił od wszelkich roszczeń rewindykacyjnych należnych mu nieruchomości poklasztornych. Na mocy umowy darowizny hrabia zrzekł się praw do kompleksu zabudowań na rzecz miasta, tym też dowodząc skuteczność działań przedsiębiorczego burmistrza.

Z inicjatywy Kuschego powołano do życia miejską kasę oszczędnościową (städtische Sparkasse), z działalności której cieszyło się już w tamtym czasie kilka miast pruskiej monarchii. Nakreślony przez niego statut, za wzór którego przyjął berlińskie rozwiązanie, został przyjęty w 1819 r. Cel i zadania instytucji wyraźnie wysłowiono w pierwszym paragrafie. W miejskiej kasie oszczędnościowej, służącej mieszkańcom miasta i wsi należących do świdnickiej kamery, pewnie i bezpiecznie lokowano środki pieniężne, które przy korzystnej stawce procentowej pozwalały uzyskać pokaźny kapitał na zabezpieczenie jesieni życia jej członków. Miasto zaś ze swojej strony gwarantowało bezpieczeństwo złożonych na konto depozytów pieniężnych. Rada miejska jednogłośnie powołała Kuschego na stanowisko księgowego instytucji. 
Jeszcze w 1821 r. dzięki staraniom burmistrza doprowadzono do reorganizacji miejskiego lombardu (städtische Leihbank), powołanego do życia w 1757 r. Przed wprowadzeniem reformatorskich zmian wydawać by się mogło, że mieszkańcy miasta zupełnie zapomnieli o działalności placówki. Kusche zabrał się z niezwykłą starannością do redagowania postanowień nowego statutu i regulaminu. W tym też celu miejscowy zarząd miejski zwrócił się do magistratów Brzegu i Wrocławia z prośbą o udostępnienie do wglądu ich rozwiązań prawnych. Projekt końcowy dokumentu poddany został ostatecznej weryfikacji przez komisję utworzoną z członków rady miejskiej, która wniosła do niego kilka poprawek. Po przejściu procedury instancyjnej w hierarchii samorządowej, ostateczną zgodę na wdrożenie statutu w życie wydały władze rejencji wrocławskiej 14 listopada $1822 \mathrm{r}^{24}$

Na mocy ordynacji miejskiej powołano, do tej pory scalony z magistratem, samodzielny organ policyjny. Skupiał on pełnię władzy w pojęciu i zakresie policji nowożytnej - począwszy od policji porządkowej, poprzez budowlaną, obyczajową, sanitarną, wodną, ogniową, do policji do spraw cenzury, nadzoru nad stowarzyszeniami, do spraw meldunkowo-paszportowych. Uprawnienia te przekazano dyrektorium, co wzbudzało powszechny wśród radnych miejskich bunt. Takie wyodrębnienie organizacyjne wiązało się ze wzrostem nakładów finansowych. Szczególne warunki, w których działało dyrektorium wymagały zatrudniania licznego personelu pomocniczego. Tworzyli go m.in. sierżanci, żandarmi i pracownicy kancelaryjni. Poza tym wychodzono z założenia, że przyznanie wyższych uposażeń pozwoli na zatrudnienie osób o lepszych kwalifikacjach, finansowo mniej zależnych, zatem dających wyższe gwarancje bezstronności. Pełnymi kosztami działalności biura policji (2230 talarów w skali roku) obciążono miejską kamerę. Memoriały do ministra spraw wewnętrznych, kierowane za pośrednictwem miejscowych deputacji, nie przyniosły spodziewanych efektów. Na nic też się zdały interwencje radnych u pruskiego króla. Kusche niestrudzenie przez 11 lat podejmował szereg starań. Zwiększające się z każdym rokiem wymagania finansowe dyrektorium spotykały się ze stanowczym sprzeciwem burmistrza, a brak jego akceptu hamował dalszą drogę postępowania. W miejskich kuluarach coraz głośniej mówiło się o jawnym konflikcie pomiędzy zarządem miasta a organem policyjnym. W maju 1815 r. wystosowano otwarty list do kanclerza von Hardenberga, w którym głównym argumentem dla zwolnienia miasta od ciężaru finansowego działalności policji było nadal fatalne położenie gospodarcze Świdnicy.

Zarząd policji, działając w porozumieniu z organami gminy miejskiej, miał prawo wydawać zarządzenia i przepisy prawa lokalnego, również wymierzać kary za ich nieprzestrzeganie. Przepisy te mogły regulować rozległą materię:

\footnotetext{
${ }^{24}$ J. Held, op. cit., s. 14-15.
} 
- ochronę osób i mienia, bezpieczeństwa, porządku i komunikacji na publicznych gościńcach, drogach, ulicach i placach,

- obrót targowy i publiczny handel żywnością,

- porządek i zgodność z prawem organizowania zgromadzeń większej liczby osób,

- publiczne dobro względem przyjęcia i przytułku obcych osób; winiarnie, szynkownie, kawiarnie i inne lokale do sprzedaży żywności i napojów,

- starania o życie i zdrowie,

- staranność przeciwko niebezpieczeństwu ogniowemu przy budowlach, jak również czyny, przedsięwzięcia i zdarzenia, które mogłyby szkodzić dobru powszechnemu bądź stanowić niebezpieczeństwo,

- ochronę pól, łąk, pastwisk, lasów, szkółek drzewnych, winnic,

- wszystko, co leży w szczególnym interesie gminy i jej mieszkańców ${ }^{25}$.

Przepisy prawne wydawane przez miejscowe organy policyjne podlegały zatwierdzeniu władz rejencji i przez nie mogły być też uchylone. Władze rejencji uprawnione były do wydawania przepisów policyjnych adresowanych do poszczególnych organów bądź też do wszystkich podległym im w terenie zarządów policji.

Pierwszym dyrektorem policji w Świdnicy został były radca ds. wojny i podatków (Kriegs- und Steuerrath) Carl August von Tepper-Lasky ${ }^{26}$. Rozdział ten trwał do 12 lutego 1820 r. Na mocy zarządzenia radcy rejencji Sohra władzę policyjną na powrót przyznano magistratowi ${ }^{27}$.

Ordynacja odebrała miastom przywileje sprawowania zarówno władzy policyjnej jak i sądowniczej, te pierwsze przekazując organom państwowym, drugie zaś władzom prowincjonalnym. W miastach powołano jednolite sądy dla miast i wsi - sądy obwodowe i miejskie I instancji (Stadt- und Landgerichte).

W XIX-wiecznej historii samorządu lokalnego kolejny etap rozwojowy wyznacza ordynacja miejska z 30 maja $1853 \mathrm{r}^{28}$, w dużym stopniu oparta

${ }^{25}$ Gesetz über die Polizei-Verwaltung vom 11. März 1850, Berlin 1850, s. 388-392.

${ }^{26}$ Ur. 6 VII 1769 r. w Drezdenku, zm. 22 II 1841 r. w Świdnicy. Najmłodszy syn Georga Antona, właściciela dużego przedsiębiorstwa handlowego w Drezdenku, edukację gimnazjalną odbywał w placówkach w Berlinie (Joachimsthal) i w okolicach Magdeburga. W 1789 r. (albo 1790 r.) podjął studia prawa, filozofii i matematyki na uniwersytecie w Halle. Około 1792 r. został praktykantem w Sądzie Nadwornym (Hofgericht) w Bydgoszczy. Od 1794 r. referendarz sądowy w Poznaniu, w 1800 r. zdał egzamin końcowy z dobrym wynikiem, zyskując zatrudnienie w administracji samorządowej. Niedługo potem objął posadę inspektora podatkowego w Łęczycy, w Księstwie Warszawskim, gdzie pracował do 1809 r., kiedy został powołany do służby w Świdnicy; zam. Köppenstr. nr 25 w kamienicy stolarza Zinnert: R. Straubel, Biographisches Handbuch der preußischen Verwaltungs- und Justizbeamten 1740-1806/15, t. II, München 2009, s. 1007.

${ }^{27}$ J. Held, op. cit., s. 15-16.

${ }^{28}$ C.F. Müller, Städte-Ordnung vom 30. Mai 1853 mit der Ausführungs-Instruktion vom 20. Juni 1853 und anderen praktischen aus den amtlichen Materialien gewonnenen Erläuterungen (...), Berlin 1853. 
na podobnych rozwiązaniach co poprzednia z $1808 \mathrm{r}^{29} \mathrm{Za}$ poprzednią ordynacją recypowano podział ludności miast na mieszkańców (Einwohner) oraz obywateli (mieszczan), czyli mieszkańców legitymujących się prawami mieszczańskimi (Bürgerrecht) ${ }^{30}$. Za mieszkańców miasta uważano wszystkich tych, którzy zgodnie z przepisami prawa posiadali w mieście miejsce zamieszkania. Do ogółu mieszkańców miast nie wliczano żołnierzy czynnej służby wojskowej stacjonujących na miejscu ${ }^{31}$. Pełne prawo mieszczańskie uprawniało do udziału $\mathrm{w}$ wyborach oraz zasiadania w zarządzie miejskim (Gemeindeverwaltung - odpowiednik magistratu) albo reprezentacji gminy (Gemeindevertretung, czyli radzie miejskiej) na zasadzie piastowania urzędów płatnych i niepłatnych. Prawo to przysługiwało jedynie samodzielnym (selbstständig) obywatelom Prus, którzy mieszkali w mieście co najmniej od roku, nie pobierali jakichkolwiek zasiłków czy zapomóg, nie zalegali z należnościami gminnymi, przy spełnieniu pozostałych szczegółowych wymagań. Przy czym za samodzielną uważano osobę, która ukończyła 24 lata, posiadała samodzielne gospodarstwo domowe, pod warunkiem, że jej ,prawo do dysponowania własnym majątkiem bądź zarząd nim nie zostały ograniczone za wiedzą sądową". Na tej podstawie magistrat wydawał Bürgerbrief, potwierdzający nabycie pełni praw mieszczańskich, w skład których wchodziło m.in. czynne i bierne prawo wyborcze.

Organami miejskiej gminy pozostały magistrat oraz rada miejska. Istotna zmiana zaszła w procedurze wyborów do rady. Wyróżniano trzy koła wyborcze (Abtheilungen), różnicując wyborców na podstawie kryterium wysokości płaconych podatków bezpośrednich (podział ten został zniesiony na rzecz powszechnego prawa wyborczego dopiero po zakończeniu I wojny światowej w 1918 r.). W 1856 r. cenzus majątkowy kształtował się w następujący sposób. Trzecia grupa dochodowa (III. Abtheilung), najliczniejsza, o najniższym dochodzie per capita, obejmowała 442 uprawnionych świdniczan, przy dochodach od 250 do 420 talarów w skali roku, druga - 227 osób przy dochodzie 420-760 talarów, pierwsza liczyła 113 uprawnionych o dochodach w granicach od 760 do 4040 talarów. W sumie, uprawnione do głosowania były 782 oso-

${ }^{29} \mathrm{~W}$ międzyczasie uchwalono w $1831 \mathrm{r}$. ustawę rewidującą pierwotną ordynację, której zarzucano przede wszystkim schematyczne rozwiązania proceduralne, zbyt niski cenzus majątkowy czy wreszcie zbyt licznie obsadzane rady miejskie. W rzeczywistości ustawa z $1831 \mathrm{r}$. wzmocniła pozycję państwowej kontroli nad działalnością samorządów lokalnych. W dużym stopniu ograniczyła również prerogatywy miejskich urzędników. Jakkolwiek ordynacja miejska Steina i Hardenberga z 1808 r. uznana została przez posłów Śląskiego Sejmu Prowincjonalnego za twór nad wyraz doskonały, tym samym rząd pruski zrezygnował, uwzględniając jednoznaczne wotum sejmu, z wprowadzenia rewidowanej ordynacji miejskiej z 1831 r. również w Prowincji Śląskiej: R. Gehrke, Landtag und Öffentlichkeit. Provinzialständischer Parlamentarismus in Schlesien 1825-1845, Köln 2009, s. 447 i n.

${ }^{30} \mathrm{~W}$ przepisach mowa jest o ,prawie mieszczańskim” (Bürgerrecht), przysługującym tym mieszkańcom miast, którzy spełniają szczegółowe kryteria, zawarte w treści $§ 5$.

${ }^{31}$ Städte-Ordnung vom 1853, § 3. 
by, przy czym do statystyki tej nie wliczono 91 właścicieli kamienic, których roczny dochód nie przekraczał 250 talarów $^{32}$. Odsetek posiadających prawo wyborcze stanowił zaledwie $0,05 \%$ mieszkańców miasta, przy uwzględnieniu danych z rok wcześniej przeprowadzonego spisu ludności (w 1855 r. ogólna liczba mieszkańców wyniosła 15 089, cywilnych: 13 173). Dla porównania, w $1871 \mathrm{r}$. odsetek ten utrzymywał się na zbliżonym poziomie przy nieznacznym wzroście w granicach $0,003 \%$. Każde koło dokonywało wyboru jednej trzeciej składu rady miejskiej, z tym że każde koło musiało składać się co najmniej w połowie z pełnoprawnych właścicieli domów (Hausbesitzern). Liczba mieszkańców Świdnicy w 1858 r. wynosiła 14757 osób, co uprawniało sformowanie rady składającej się z 30 reprezentantów. Utrzymano jednak dotychczasową liczbę 36 radnych, na co pozwalał przepis $\S 12$.

Nowa ordynacja wprowadziła istotne ograniczenia w wyborze do rad. Radnym nie mogła zostać m.in. osoba duchowna, służba kościelna, nauczyciel elementarny, urzędnik policyjny. Również osoby pozostające w pierwszym stopniu pokrewieństwa i rodzeństwo (oczywiście wyłącznie płci męskiej) nie mogły zasiadać w tym samym składzie rady ${ }^{33}$. Kobiet z założenia nie dopuszczano w tych czasach do piastowania urzędów, choć zakazu tego nie wysłowiono w sposób bezpośredni. Nawet wprowadzona w drodze rozporządzenia w 1847 r. jawność posiedzeń rad miejskich nie uprawniała kobiet do udziału w charakterze publiczności. Zdarzało się jednak widywać je na widowni w sali sesyjnej. Szybko też w urzędowych publikatorach ukazało się stosowne wyjaśnienia ministra spraw wewnętrznych, w którym upoważniał on przewodniczących rad miejskich do niedopuszczania publiczności na posiedzenia, a gdyby ta wtargnęła siłą - polecał zamknięcie obrad ${ }^{34}$.

Jawność obrad miejskich parlamentów wprowadzono w monarchii pruskiej w 1847 r. Jednak kilka lat wcześniej, w 1843 r. śląski sejm prowincjonalny (schlesische Provinzial-Landtag) skierował do pruskiego monarchy petycję $\mathrm{w}$ sprawie upublicznienia przebiegu posiedzeń. Postępowy wniosek zgłosił VII sejm prowincjonalny, toczący obrady w okresie 5 III - 5 V 1843 r. W jego treści zwrócono się do króla, aby ten wprowadził stosowne modyfikacje w ordynacji miejskiej z 1808 r. zaprowadzając otwarte dla publiczności obrady miejskich parlamentów oraz powszechność dostępu do treści podejmowanych uchwał. Panujący powszechnie w całych Prusach do początku lat czterdziestych XIX w. marazm polityczny zaczynał ustępować miejsca śmiałym inicjatywom wysuwanym przez nowo powstające koła opozycji mieszczańskiej i wiejskiej, szczególnie popieranych przez rzemieślniczą biedotę, bytującą na krawędzi ubóstwa. Były to pierwsze sygnały „wrzenia przedmarcowego". Silne tendencje opozycyjne wzięły głos podczas obrad sejmu pro-

${ }^{32}$ Bericht (...) für das Jahr 1856, Schweidnitz 1857, s. 4.

${ }^{33}$ Städte-Ordnung vom 1853, § 17.

${ }^{34}$ K. Ciesielska, op. cit., s. 66. 
wincjonalnego zwołanego w 1843 r. Z mnogiej liczby zgłoszonych petycji, jawnie manifestujących radykalizujące się nastroje społeczne, zgłoszono królowi zaledwie nikły ich odsetek. Dyskutowano nad nadaniem większej samodzielności sejmom prowincjonalnym celem wzmocnienia ich pozycji, powołaniem ogólnokrajowego zgromadzenia stanów Rzeszy, w końcu też pod obrady wzięto sprawę jawności obrad samego sejmu prowincjonalnego, sądu czy, wreszcie, rad miejskich.

Problem jawności posiedzeń, przede wszystkim w wymiarze dopuszczenia publiczności i dostępu do uchwał organów miejskiego samorządu, uderzał w treść $\S 113$ ordynacji miejskiej, traktującego o udziale w obradach rady miejskiej wyłącznie członków zgromadzenia. Proponowana zmiana przepisu motywowana była postulatami zaprowadzenia otwartego i transparentnego charakteru działalności organów obieranych w demokratycznych wyborach. Przedstawiciele mieszczaństwa zasiadający w radach miejskich nie zawsze pozostawali wierni deklarowanym poglądom i ideałom, toteż społeczna kontrola ich działalności była jak najbardziej wskazana. Wniosek posłów uzupełniał postulat publikowania sprawozdań rad miejskich i komisji. Wprawdzie włodarze Wrocławia podnosili podobne hasła już w 1841 r., opowiadając się za dopuszczeniem publiczności na posiedzenia radnych miasta, jednak temat ten szybko zarzucono. Aby zmiany te mogły wejść w życie, wymagana była nowelizacja przepisów m.in. ordynacji miejskiej z 1808 r. Petycja trafiła do rąk Fryderyka Wilhelma IV i nie spotkała się z dobrym przyjęciem. Zbyt liberalny na tamte czasu postulat wprowadzenia jawności został odrzucony w recesie z 30 XII 1843 r. $^{35}$ Monarcha zajął również stanowisko względem drugiego postulatu, wskazując, iż już na gruncie instrukcji dla radnych miejskich, stanowiącej załącznik do ordynacji miejskiej z 1808 r., istnieje możliwość pu-

${ }^{35}$ Podobne żądania deputowani zgłosili w trakcie VIII sejmu prowincjonalnego, podnosząc argument, iż jawność obrad czyniłaby zadość nie tylko ogólnospołecznym interesom, służyłaby również indywidualnym wyborcom. Taki stan porównano z posiedzeniami landtagu, których przebieg utrwalano w formie drukowanej od 1843 r. (na podstawie rozkazu gabinetowego Fryderyka Wilhelma IV z 19 IV 1843 r.). Zatem najbardziej pożądane w tej materii byłyby zmiany ustawodawcze. Wniosek poselski uzupełniła opinia nadprezydenta rejencji wrocławskiej von Merckela. W swoich uwagach nadmienił, iż petycja pochodzi jedynie od deputowanych do sejmu prowincjonalnego, zaś jego prywatnym zdaniem, postulat jest trafny, jednak wymaga drobnych poprawek. Dopuszczenie widzów do posiedzeń organów kolegialnych gmin miejskich stanowiłoby próbę politycznego kształcenia społeczeństwa. Jednakże jawność ta miałaby się ograniczać do prawa wstępu na posiedzenia, zaś treść ich przebiegu winna być ocenzurowana. Wniosek został ponownie odrzucony przez monarchę w piśmie z dnia 27 XII 1845 r. Natomiast aprobatę zyskał drugi z postulatów dotyczący publikowania sprawozdań z przebiegu posiedzeń, jednakże w okrojonej wersji. Cenzurą miano bowiem objąć m.in. różnice zdań i spory powstające pomiędzy członkami w trakcie sesji, gdyż, jak motywował król, mogłoby to powodować szczególne szkody. Problem ten nie został rozwiązany do wydarzeń Wiosny Ludów: Verhandlungen des achten Provinzial-Landtages des Herzogthums Schlesien, der Grafschaft Glatz und des Markgrafthums Ober-Lausitz, Preussischen Antheils, nebst dem von Seiner Majestät dem Könige darauf ertheilten Allerhöchsten Landtags-Abschiede vom 27. Dezember 1845, Breslau 1846, s. 119 i n. 
blikowania przebiegu obrad i treści uchwał na łamach miejscowych poczytnych periodyków ${ }^{36}$. Za fasadą swobody krył się jednak szereg szczegółowych restrykcji, m.in. konieczność uprzedniej konsultacji z władzami magistrackimi treści planowanych publikacji oraz kontrola dopuszczalności sprawowana przez cenzora $^{37}$.

Gorącym orędownikiem upublicznienia obrad była świdnicka rada miejska, która jeszcze 25 I 1844 r. jednogłośnie zdecydowała o wydawaniu drukiem relacji z przebiegu każdego posiedzenia, korzystając tym samym $\mathrm{z}$ uprawnienia przysługującego jej na mocy $\S 40$ „Instrukcji w sprawie postępowania radnych miejskich podczas regularnych posiedzeń" (Instruktion behufs der Geschäftsführung der Stadtverordneten bei ihren ordnungsmäßigen Versammlungen):

Po tym, jak siódmy Sejm Prowincjonalny, debatujący w dniu 30 XII 1843 r. nad petycją $\mathrm{w}$ sprawie upublicznienia posiedzeń rad miejskich, nie odniósł się do niej przychylnie, zdecydowaliśmy za porozumieniem z szacownym magistratem podczas dzisiejszego posiedzenia, aby nasze działania, podejmowane na plenum rady zostały upublicznione $\mathrm{w}$ formie druku $\mathrm{w}$ takim zakresie, $\mathrm{w}$ jakim dotyczą interesu powszechnego, nie dotykając spraw prywatnych. Pragniemy ukazać całemu mieszczaństwu, a tym samym utwierdzić je w przekonaniu, w jaki sposób staramy się sprostać pokładanemu w nas zaufaniu ${ }^{38}$.

Takie działanie motywowane było „nadzieją, że poprzez upublicznienie posiedzeń całe mieszczaństwo Świdnicy wykaże jeszcze większe i bardziej żywe zainteresowaniem działalnością samorządu miejskiego, co też wzmocni ducha mieszczańskiej solidarności i poczucie obywatelskiej tożsamości, płynące z ordynacji miejskiej”. Prawdopodobnie Świdnica jako jedno z pierwszych miast pruskiej monarchii wdrożyła zasadę formalnej jawności posiedzeń ${ }^{39}$. Postępowe, choć zarazem radykalne na tamte czasy posunięcie nie od razu przypadło do gustu władzy wykonawczej, mimo udzielonej przez nią uprzednio zgody. Co było też przyczyną zgłoszonego przez kolegium magistrackie sprzeciwu wydania drukiem wyciągu z kolejnych obrad z 22 lutego 1844 r., pozostaje w sferze domysłów. Decyzja ta została podsumowana przez przewodniczącego rady, wypowiadającego się w imieniu całego zgromadzenia, słowami: „Takie jest nasze usprawiedliwienie”. Problem ten pobudzał

${ }^{36}$ T. Kruszewski, Ordynacja miejska z 1808 r. w uchwałach sejmu prowincjonalnego na Ślasku (1825-1845), [w:] Miasta i prawo miejskie w rozwoju historycznym. Materiały VI Konferencji Historyków Państwa i Prawa, Ladek Zdrój 9-11 września 2002, Wrocław 2003, s. 80-81.

${ }^{37}$ T. Kruszewski, Sejm Prowincjonalny na Śląsku (1824-1933), Wrocław 2000, s. 103-104.

${ }^{38}$ Verhandlungen der Stadt-Verordneten zu Schweidnitz, Schweidnitz 1844, s. 1.

${ }^{39}$ Dla porównania, jawność obrad rad miejskich wprowadzono w Jeleniej Górze w październiku 1847 r., w Kamiennej Górze - dopiero we wrześniu 1849 r.: J. Sydor, Wiosna Ludów w powiatach górskich Dolnego Ślaska, Wrocław 1969, s. 63. 
do ożywionej dyskusji i debaty nad fundamentalnymi swobodami obywatelskimi, do jakich bezsprzecznie wlicza się prawo do kontroli działalności organów wybieranych w drodze demokratycznych wyborów. Kolejny wyciąg z posiedzenia ukazał się drukiem 23 marca i podsumowywał zgromadzenie z 5 marca. Pod obrady wzięto szereg spraw, w tym złożone na ręce radnych zarządzenie władz rejencji wrocławskiej z 18 lutego poparte pismem tutejszego magistratu w sprawie jawności posiedzeń parlamentu miejskiego. Dokument urzędników rejencji był w rzeczywistości kopią rezolucji adresowanej do wrocławskiej rady miejskiej, która na wzór świdnickiej czyniła starania ku upublicznieniu przebiegu jej posiedzeń ${ }^{40}$. Ciąg niekończących się sporów na tym tle ucięło zarządzenie gabinetowe Fryderyka Wilhelma IV z 19 kwietnia 1844 r. ${ }^{41}$, w którym kwestie te zostały ostatecznie uregulowane na korzyść miejskich parlamentów. Do kompetencji rady i magistratu należała decyzja o kolportowaniu drukowanych sprawozdań z posiedzeń, których treść miała być zaaprobowana przez komisję redakcyjną (Redaktions-Kommission) złożoną z członków rady i obradującą pod przewodnictwem przedstawiciela władzy magistrackiej. Pozostawiono też urząd niezawisłego cenzora, czuwającego nad polityczną poprawnością treści ogłoszeń ${ }^{42}$.

Kadencja rady wynosiła 6 lat, zaś co 2 lata jej skład był odnawiany w jednej trzeciej w tzw. wyborach uzupełniających (Ergänzungswahlen), które od-

${ }^{40}$ Radni Wrocławia podjęli równie zdecydowane kroki i jeszcze w 1843 r. zaczęli wydawać drukiem protokoły zebrań rady miasta, co nie umknęło uwadze tamtejszego magistratu. Niezwłocznie podjęte działania zakazującej takiej działalności natrafiły na równy opór urzędników samorządowych i społeczności lokalnej; w rezultacie spór oddano pod sąd wyższej instancji władz rejencji. Ta zaś w treści swojej decyzji wpierw dokonała wykładni obowiązujących przepisów, w tym $\S 183$ ordynacji miejskiej z 1808 r., który zezwala na publikowanie wyciągów z miejskich rachunków opatrzonych opisem co do perspektyw rozwojowych, ostrzeżeń czy decyzji dotyczących finansów. Najwięcej zaś wątpliwości interpretacyjnych wzbudzał § 40 „Instrukcji w sprawie postępowania radnych miejskich podczas regularnych posiedzeń" (Instruktion behufs der Geschäftsführung der Stadtverordneten bei ihren ordnungsmäßigen Versammlungen), który uznawano za silne uzasadnienie dla publikacji wyciągów z protokołów rad miejskich. Treść tej regulacji miała również legitymować postępowanie świdnickich radnych. Jak chwiejne to były podstawy, dowiódł reskrypt ministerialny, w którym na pytanie, czy publikacja historycznych wyciągów z protokołów, wywołujących nadal skutki prawne, jest dozwolona, udzielono zdecydowanie negatywnej odpowiedzi. Jakkolwiek władzom samorządowym pozostawiono swobodę uznania, czy w granicach obowiązującego prawa dopuszczać do publikacji ocenzurowanych ekstraktów z protokołów posiedzeń.

${ }^{41}$ Allerhöchste Kabinetsorder vom 19. April 1844., die Veröffentlichungen über die Wirksamkeit der städtischen Behörden und Vertreter betreffend, [w:] Gesetz-Sammlung für die Königlichen Preussischen Staaten 1844, Nr 10.

${ }^{42}$ Otwarty konflikt pomiędzy świdnicką radą miejską a magistratem dostatecznie ujawnia treść petycji radnych, skierowanej w 1845 r. pod obrady VIII Sejmu Prowincjonalnego we Wrocławiu. Memoriał dotyczył rozszerzenia zarządzenia gabinetowego wydanego przez pruskiego monarchę 19 IV 1844 r. w sprawie upublicznienia działalności miejskich parlamentów. Radni domagali się interwencji u króla celem nadania radom większej autonomii w materii publikowania sprawozdań z ich posiedzeń bez konieczności pośrednictwa instancji magistratu: Verhandlungen der Stadt-Verordneten zu Schweidnitz in dem ersten Semester 1845, Schweidnitz 1845. 
bywały się w listopadzie. Ważkość tego działania, zgodnie z przepisami ordynacji, miała być podkreślana w kazaniu głoszonym podczas ostatniego przed wyborami nabożeństwa (§ 21). Listy uprawnionych do głosowania były ogłaszane przez magistrat w lipcu każdego roku. W każdym okręgu wyborczym (Wahlbezirk), na czas wyborów formowano komisje wyborcze, składające się $\mathrm{z}$ burmistrza bądź jednego z zastępców w charakterze przewodniczącego komisji oraz z 2 członków dotychczasowego składu rady miejskiej jako asesorów (Beisitzern). Wybory rządziły się zasadą ustności. Każdy wyborca, chcący oddać ważny głos, zobowiązany był stawić się przed komisją, udzielając ustnie i głośno (mündlich und laut) poparcia dla jednego bądź kilku kandydatów. Zakres uprawnień rady miejskiej powielono z poprzedniej ordynacji. Posiedzenia odbywały się tak często, jak tego wymagała działalność organu, przy czym prawo do zwołania posiedzenia posiadał przewodniczący rady, jedna czwarta jej składu oraz magistrat. Co istotne, posiedzenia rady miejskiej były jawne. Wprowadzono również zakaz odbywania zebrań miejskiego parlamentu w gospodach i szynkach (§ 45). Sesje świdnickiego parlamentu odbywały się w kościele św. Krzyża (Kreuzkirche), który od czasu sekularyzacji dóbr kościelnych (1810) pozostawał w prywatnych rękach (początkowo własność jednego z pierwszych żydowskich osadników na terenie Świdnicy - Wolfa Lohnsteina, potem J. Dittricha, pana na dobrach w Mokrzeszowie, który w 1827 r. wystawił obiekt na sprzedaż $)^{43}$. W zaadaptowanym na cele handlowo-usługowe wnętrzu świątyni prowadzono sklep i magazyn, na piętrze urządzono mieszkania i salę obrad miejskiej rady. Parter budynku dawnej komendy krzyżowców zagospodarowano na cele mieszkalne. Wydzielono mieszkanie z trzema izbami, kuchnią, piwniczką, poddaszem, drewutnią, do tego przynależała wolnostojąca stajnia na trzy bądź sześć koni oraz wozownia. Poza działalnością miejskiej administracji, pomieszczenia kościelne służyły przez pewien okres (od kwietnia 1853 r.) miejscowej gminie dysydenckiej, której dotychczasowa siedziba - kościół garnizonowy - przechodziła remont dachu. W $1851 \mathrm{r}$. w obiekcie przez jakiś okres funkcjonowała landratura ( $\mathrm{Kgl}$. Landrats-Amt; jeszcze w 1859 r.) W tamtym czasie właścicielem Kreuzkirche był radny Löwel. W 1848 r. ukończono przebudowę smatruzu (Schmetterhaus), mieszczącego się w Rynku, nad głównym odwachem (Haupt-Wache), gdzie docelowo miano wygospodarować salę posiedzeń miejskiej rady. Pierwsze zebranie członków w nowej siedzibie miało miejsce 1 października $1848 \mathrm{r}$.

Magistrat jako kolegialny organ wykonawczy został wyposażony w szereg uprawnień. W szczególności przysługiwało mu prawo wydawania zarządzeń i przepisów prawnych o zasięgu lokalnym, przedkładał radzie miejskiej

${ }^{43}$ Nowym właścicielem zabudowań kościelnych został kupiec Friedrich Wilhelm Löwel, który prowadził sklep z artykułami tabacznymi i przyprawami przy Langstr. nr 267. 
projekty uchwał, zatrudniał niektórych urzędników gminnych (za uprzednim wysłuchaniem przez radę), zarządzał działalnością gminnych instytucji i zakładów, administrował gminnym majątkiem i dochodami, kontrolując i nadzorując przedstawiane mu rachunki i sprawozdania finansowe $\mathrm{z}$ dotychczasowej działalności. Poza tym, pełnił funkcję reprezentacyjną, będąc umocowanym do podejmowania działań oraz zaciągania zobowiązań w imieniu całej gminy miejskiej. W ramach działalności administracyjnej powoływano deputacje lub komisje, których celem statutowym było sprawowanie trwałego zarządu bądź nadzoru nad poszczególnymi przedsięwzięciami albo ukończenie przedsięwziętego zlecenia. Skład w tych jednostkach mógł przedstawiać się następująco. Mogli je tworzyć wyłącznie członkowie magistratu albo członkowie obu organów gminy. Dopuszczano również uzupełnienie składu mieszkańcami miasta uprawnionymi do głosowania. W przypadku, gdy funkcje organu policyjnego nie były wykonywane za pośrednictwem urzędników królewskich, uprawnienia te skupiał burmistrz ${ }^{44}$. Świdnickie kolegium magistrackie gromadziło się zazwyczaj w ratuszu, regularnie we wtorki i niedziele.

W 1864 r., po 12 latach kadencji na czele świdnickiego magistratu, wygasł mandat nadburmistrza Gustava Glubrechta ${ }^{45}$. W wyniku przeprowadzonych w tym samym roku wyborów prawie jednomyślnie powołano go ponownie na urząd. Reelekt został zatwierdzony przez króla Wilhelma I, a 19 maja 1864 r., w obecności królewskiego komisarza rejencji wrocławskiej, asesora Tschoppego, miało miejsce uroczyste zaprzysiężenie i wprowadzenie burmistrza na urząa $^{46}$.

W większych miastach utrzymano podział na okręgi z przewodniczącym na czele. Tym razem podkreślono, iż przewodniczący okręgów byli organami magistratu, podlegli jego zaleceniom i nakazom.

W końcowych postanowieniach ordynacji zawarto przepis zobowiązujący wszystkich obywateli miast uprawnionych do głosowania do przynajmniej jednorazowego piastowania niepłatnych (honorowych) urzędów w magistracie bądź radzie miejskiej, przez okres co najmniej 3 lat (§ 74). Taka forma przymusu obarczona była zarówno wadami, jak i zaletami. $Z$ jednej strony, aktywizowano miejscową społeczność do działań w dziedzinie polityki lokalnej, dając jej możliwość choćby iluzorycznego wpływu na życie miejskie. $\mathrm{Z}$ drugiej zaś, forma ta agresywnie ingerowała $\mathrm{w}$ sferę wolności obywatelskich, czyniąc z fundamentalnej wolności osobistej (persönliche Freiheit)

${ }^{44}$ Städte-Ordnung vom 1853, § 56 i n.

${ }^{45}$ Po śmierci burmistrza J.B. Kuschego ( $† 2$ X 1832), na urząd przewodniczącego magistratu wybrano Ferdinanda Berlina, który pełnił funkcję w latach 1832-1848. Po rozruchach 1848 r. ustąpił ze stanowiska. W tym samym roku władze rejencji ustanowiły zarząd komisaryczny w osobie asesora Schmidta z Wrocławia (do 1851 r.). W wyniku przeprowadzonych 1 XII 1851 r. wyborów urząd burmistrza obsadził Gustav Glubrecht.

${ }^{46}$ OB 1863, nr 43; 1864, nr 20. 
wywalczonej i zagwarantowanej w pruskiej konstytucji z 5 grudnia 1848 r., następnie potwierdzonej w artykule 5 ustawy zasadniczej z 31 stycznia $1850 \mathrm{r}$. - wolność iluzoryczną.

Nowa ordynacja miejska w sposób kompleksowy regulowała działalność, struktury i uprawnienia organów samorządowych, zastępującym tym samym ordynację gminną z 11 marca 1850 r. (Gemeinde-Ordnung). Derogowana ustawa urzeczywistniała uchwaloną w tym samym roku konstytucyjną zasadę samodzielności i niezależności samorządu terytorialnego (art. 105 ust. 3: Den Gemeinden insbesondere steht die selbstständige Verwaltung ihrer Gemeindeangelegenheiten unter gesetzlich geordneter Oberaufsicht des Staats $z u$ ), ograniczając tym samym szerokie kompetencje administracji państwowej w zakresie nadzoru nad działalnością samorządową. Zasada ta przyświecała również ordynacji miejskiej z 1853 r. 